ACTA THERIOLOGICA

Vol. 32, 7: 95-104, 1987

\title{
Topography and Structure of Corpus striatum in Insectivora
}

\author{
Stanisław SZTEYN, Barbara GAWRONSSKA \& Edward SZATKOWSKI
}

\begin{abstract}
Szteyn St., Gawrońska B. \& Szatkowski E., 1987: Topography and structure of corpus striatum in Insectivora. Acta theriol, 32, 7: 95-104 [With Plates III-IV].

The telencephalon was studied in three species of Insectivora: Sorex araneus, Neomys fodiens and Talpa europaea. The material was fixed in formalin, dehydrated in ethyl alcohol, embedded in paraffin and cut into transverse sections $15 \mu \mathrm{m}$ thick. The sections were stained by the methods of Nissl and Klüver and Barrera. The corpus striatum of Insectivora is divided into the striatum, the nucleus accumbens and the globus pallidus. In $S$. araneus and $N$. fodiens the striatum is a homogenous band of cells. Only in the middle part the fascicles of the fibres of the internal capsule separate partly the central part of the striatum into a lateral and medial part. In $T$. europaea the striatum is divided into the nucleus caudatus and putamen and only in the anterior and posterior parts both nuclei are fused. The nucleus accumbens and the globus pallidus in Insectivora show no significant species-specific differences. As compared with higher mammals the septal part of the nucleus accumbens is relatively poorly developed in Insectivara.

[Teachers' Training College, Department of Vertebrates Anatomy, ul. Żołnierska 14; 10-561 Olsztyn, Poland].
\end{abstract}

\section{INTRODUCTION}

The purpose of the study was to gain an insight into the situation, structure and cells forms of the corpus striatum in certain mammals from the order Insectivora. The structure of the central nervous system in these animals shows numerous primitive features which are interesting from the standpoint of comparative anatomy. In view of this a study was undertaken on the corpus striatum in certain species from this order of mammals.

\section{MATERIAL AND METHOD}

The study was carried out on the brains of three species from the Insectivora order: mole (Talpa europaea Linnaeus, 1758), common shrew (Sorex araneus Linnaeus, 1758) and water shrew (Neomys fodiens Pennat, 1771). The material for the investigations was fixed in formalin, dehydrated in graded ethyl alcohol, and embedded in paraffin cutting it then into transverse sections $15 \mu \mathrm{m}$ thick. The sections were stained by the methods of Nssl and Klüver-Barrera. 
The following division of the corpus striatum was accepted:

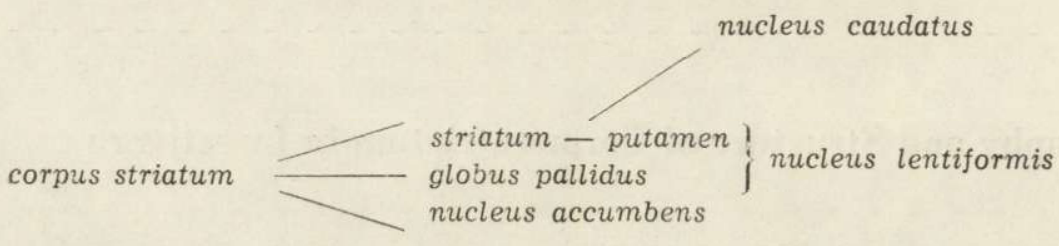

\section{RESULTS}

Striatum (St). The striatum in S. araneus (St-Fig. 1, 2, Plate III) lies in the subcortical part of the telencephalic hemisphere dorsally to the other subcortical structures of the telencephalon. It is not divided into the nucleus caudatus and the putamen, but is formed by a homogenous band of cells sharply delineated from the globus pallidus which lies in the middle part of St. The anterior pole of the St lies about $600 \mu \mathrm{m}$ pnsteriorly to the anterior end of the frontal horn of the lateral ventricle. The posterior pole lies about $300 \mu \mathrm{m}$ from the posterior end of the nucleus amygdalae. The $S t$ is about $1.67 \mathrm{~mm}$ long.

On the transverse sections the anterior part of the St appears as an oval group of cells situated on the ventrolateral aspect of the lateral ventricle. This group of cells increases in size posteriorly filling the space between the wall of the lateral ventricle and the external capsule which forms the boundary of the $S t$ on the lateral and ventral sides. About $700 \mu \mathrm{m}$ from the anterior pole of the St delicate fascicles of fibres begin to penetrate between the cells of the $S t$, and they fan out in the lateral direction. Some of them reach the external capsule. At the level of the anterior pole of the globus pallidus the St assumes on the transverse cross-sections the shape of a bean, with its convex surface pointing laterally. At a distance of about $400 \mu \mathrm{m}$ from the posterior pole the fanlike fascicles of fibres are no longer visible, and the $S t$ decreases gradually in size and shifts laterally. The terminal part of the $S t$ is a narrow group of cells adjacent to the external capsule. In the dorsal part of the St delicate fascicles of the fibres of the internal capsule appear between its cells. Their arrangement is irregular and they form no larger aggregates.

In $S$. araneus the $S t$ is formed of densely crowded rounded and multipolar cells $10-20 \mu \mathrm{m}$ in diameter, with poorly discernible nucleus and intensively staining nucleolus. The tigroid is present in a form of small granules (Fig. 5, Plate IV).

The situation and the shape of the $S t$ in $N$. fodiens are not different. from those in $S$. araneus, and similarly as in $S$. araneus it is not divided into the caudate nucleus and the putamen. The anterior pole of the $S t$ 
in $N$. fodiens lies about $360 \mu \mathrm{m}$ posteriorly from the anterior end of the lateral ventricle, and the posterior pole is situated about $200 \mu \mathrm{m}$ behind the posterior pole of the nucleus amygdalae. The length of the $S t$ is about $2.8 \mathrm{~mm}$. The $S t$ in $N$. fodiens is formed by cells very similar to those in the $S t$ in $S$. araneus, but they are arranged much more densely (Fig. 7, Plate IV).

In $T$. europaea the $S t$ shows an evident division into the nucleus caudatus and the putamen which are fused only near both poles. The nucleus caudatus in T. europaea (Nc-Fig. 3, 4, Plate III) lies in the subcortical part of the telencephalic hemispheres, closely adjacent to the lateral wall of the anterior horn of the lateral ventricle. The anterior pole of the nucleus caudatus lies about $1.4 \mathrm{~mm}$ posteriorly to the anterior pole of the lateral ventricle, and the posterior pole lies about $600 \mu \mathrm{m}$ anteriorly to the posterior pole of the amygdaloid nucleus. The length of the nucleus caudatus is about $4.3 \mathrm{~mm}$.

The anterior pole of the nucleus caudatus and the putamen is formed by an oval group of cells adjacent to the lateral wall of the lateral ventricle. About $360 \mu \mathrm{m}$ posteriorly to the anterior pole numerous fibres of the internal capsule appear and separate the medially situated nucleus caudatus from the laterally lying putamen. The nucleus caudatus assumes the shape of a vertical oval. On the medial side it is limited by the lateral wall of the lateral ventricle, on the lateral side by the internal capsule, and dorsally by the corpus callosum. Below, the caudate nucleus meets the anterior comissure. At a distance of about $1.7 \mathrm{~mm}$ posteriorly from the anterior pole the nucleus caudatus assumes the shape of a club with its broader part adjacent to the corpus callosum, tapering off posteriorly and assuming the shape of a triangle with its base adjacent to the corpus callosum. The number of the fibres from the internal capsule increases, and the nucleus caudatus is connected to the putamen only with a narrow bridge of cells. About $2.8 \mathrm{~mm}$ posteriorly to the anterior pole the nucleus caudatus is completely separated from putamen by the fibres of the internal capsule and the nucleus caudatus has an oval shape. About $50 \mu \mathrm{m}$ anteriorly from the posterior pole the caudate nucleus and the putamen are again connected by bridges of cells, and about $200 \mu \mathrm{m}$ from the posterior pole both these nuclei are completely fused. The group of cells forming the posterior part of these nuclei tapers off and disappears completely.

In the mole the caudate nucleus is formed by multipolar and rounded cells $10-20 \mu \mathrm{m}$ in size. They contain a light-staining nucleus with an intensely staining nucleolus, and microgranular tigroid (Fig. 9, Plate III).

The putamen of the mole (Pt-Fig. 3,4) lies in the subcortical part of the telencephalic hemisphere, laterally to the other nuclei in this 
region. The anterior and posterior poles are common to both these nuclei, and the length of $\mathrm{Pt}$ and $\mathrm{Nc}$ is also common. At the site of $\mathrm{St}$ division into two nuclei the $P t$ lies laterally to the caudate nucleus. In this place the putamen has the shape of a vertical oval. The lateral boundary of the nucleus is formed by the external capsule, the medial one by the internal capsule, and dorsally the nucleus is limited by the corpus callosum. The ventromedial part of the $P t$ lies in close vicinity to the anterior commissure. About $500 \mu \mathrm{m}$ from the anterior pole the nucleus accumbens appears on the ventral side of the putamen. In view of the similarity in the cellular arrangement of both it is very difficult to establish an exact boundary between them. After the appearance of the globus pallidus the putamen assumes the shape of a bean with the globus pallidus situated in its hilus. The dorsal part of the putamen is divided by the fibres running fan-like to the corpus callosum and internal capsule. In the posterior part these fibres divide also the middle part on the putamen, and they are absent only in the ventral part. The putamen and the nucleus caudatus are bound again by isolated cell bridges at first, and at a distance of about $300 \mu \mathrm{m}$ from the posterior pole they are fused forming one cell mass, which tapers of gradually and disappears as an oval group of cells. The putamen in the mole is composed of the same cells as the caudate nucleus.

Nucleus accumbens $(\mathrm{Na}$ ). The nucleus accumbens in $\mathrm{S}$. araneus ( $\mathrm{Na}$, Nas-Fig. 1) lies in the subcortical part of the telencephalic hemispheres, ventrally to the remaining structures of the corpus striatum. The anterior pole of the $N a$ lies about $50 \mu \mathrm{m}$ posteriorly to the anterior pole of the striatum. The posterior pole of this nucleus is situated about $900 \mu \mathrm{m}$ anteriorly from the posterior pole of the St. The length of the $\mathrm{Na}$ is about $700 \mu \mathrm{m}$.

The anterior pole of the nucleus accumbens is formed by an oval group of cells separated from the ventral surface of the St by a horizontal band of fibres. Posteriorly, the nucleus increases in size in the ventromedial direction. At a distance of about $90 \mu \mathrm{m}$ from the anterior pole the $\mathrm{Na}$ encircles the anterior commissure on the ventromedial side, and with a narrow band of cells it is connected to the inferior surface of the striatum. This band is adjacent on the medial side to the septum pellucidum, and is called the septal part of the nucleus accumbens (Nas). At this level the boundary between the $S t$ and the remaining part of the $N a$ becomes less well visible. The lateral surface of the $N a$ is limited by the external capsule. At a distance of about $200 \mu \mathrm{m}$ posteriorly from the anterior pole the anterior commissure meets the floor of the lateral ventricle which causes that the Nas and the $S t$ become separated. The septal part of the $\mathrm{Na}$ lying on the medial side of the anterior commissure 
disappears gradually. At half the length of the $N a$ the anterior commissure of the left side meets that of the right side and the Nas disappears there. About $400 \mu \mathrm{m}$ posteriorly from the anterior pole of the $N a$ between this nucleus and the $S t$ fibres of the posterior part of the anterior commissure penetrate there and divide both these nuclei. The $\mathrm{Na}$ assumes the shape of the letter " $U$ " with widely spread arms meeting the posterior part of the anterior commissure, and without changing this shape it tapers off and disappears. The $\mathrm{Na}$ in $\mathrm{S}$. araneus is composed of the same cells as the striatum.

In $N$. fodiens the $N a$ lies vertrally to the remaining structures of the corpus striatum. The anterior pole of the $N a$ is situated at a distance of about $150 \mu \mathrm{m}$ posteriorly from the anterior pole, and the posterior pole lies $1.4 \mathrm{~mm}$ anteriorly to the posterior pole of the striatum. The length of the nucleus accumbens is about $1.2 \mathrm{~mm}$.

The anterior pole of the $N a$ is formed by an oval group of cells on the ventral surface of the St. The boundary between the $N a$ and the striatum is not distinct. It is formed by few very thin fascicles of fibres coursing horizontally from the anterior commissure towards the external capsule. Posteriorly, the $\mathrm{Na}$ increases in size rapidly in the ventromedial direction. At a distance of about $120 \mu \mathrm{m}$ posteriorly from the anterior pole medially from the anterior commissure a small cell group appears. This group increases in size and joins the ventral surface of the $\mathrm{Na}$ and nucleus caudatus. The lateral boundary of the $N a$ is formed by the external capsule, while the medial one is the septum pellucidum to which the septal part of the $N a$ is adjacent. About $240 \mu \mathrm{m}$ posteriorly from the anterior pole the anterior commissure meets the floor of the lateral ventricle. This leads to separation of the septal part of the $\mathrm{Na}$ from the St. In the posterior direction the septal part disappears gradually. At a distance of about $750 \mu \mathrm{m}$ posteriorly from the anterior pole the anterior commissure of both hemispheres meet. The nucleus accumbens assumes the shape of the letter " $U$ " and its arms adjacent to the posterior part of the anterior commissure. The $\mathrm{Na}$ disappears as a small group of cells closely adjacent to the posterior part of the anterior commissure. In $\mathrm{N}$. fodiens the $\mathrm{Na}$ is formed of the same morfologically cells as the $S t$ which are somewhat more densely arranged (Fig. 8, Plate IV).

In the mole the $\mathrm{Na}(\mathrm{Na}, \mathrm{NaC}-\mathrm{Fig} .3)$ is situated ventrally to the caudate nucleus and putamen. The anterior pole of this nucleus lies at a distance of about $480 \mu \mathrm{m}$ posteriorly to the anterior pole of the putamen, and the posterior pole lies at a distance of $1.74 \mathrm{~mm}$ anteriorly to the posterior pole of the putamen. The length of the $N a$ is about $2.0 \mathrm{~mm}$. On the transverse cross-sections the anterior pole of the $\mathrm{Na}$ 
is formed by an oval group of cells situated on the ventral aspect of the putamen. The boundary between the putamen and the $N a$ are not numerous fascicles of fibres running horizontally from the anterior conmissure to the external capsule. At this level the cells of the ventral part of the caudate nucleus penetrate into the space between the lateral ventricle and the anterior commissure forming the caudate part of the nucleus accumbens $(\mathrm{Nac})$. At a distance of about $250 \mu \mathrm{m}$ posteriorly to the anterior pole, in the space between the $\mathrm{Nac}$ and $\mathrm{Na}$ an oval group of cells appears fuses posteriorly with the dorsal surface of the $N a$ and ventral surface of the Nac. This group forms in T. europaea the septal part of the nucleus accumbens (Nac). At this site also the $N a$ is best developed. Its lateral boundary is the internal capsule, and the medial one is the septum pellucidum. The boundary between the caudate nucleus and the $\mathrm{NaC}$ is indistinct in view of the similarity in the arrangement of cells. The anterior commissure reaches the floor of the lateral ventricle at a distance of about $480 \mu \mathrm{m}$ posteriorly to the anterior pole of the $\mathrm{Na}$ and the $\mathrm{Nac}$ disappears at this level. The cells of the $\mathrm{Na}$ encircle the anterior commissure on the lateral, ventral and medial sides. In the posterior direction the posterior direction the Nas decreases in size and disappears from the dorsal side. At a distance of about $1.4 \mathrm{~mm}$ posteriorly to the anterior pole of the $N a$ the right and left anterior commissures meet and at this site the Nas disappears. The posterior part of the anterior commissure separates the $\mathrm{Na}$ from the putamen. The $\mathrm{Na}$ disappears as a group of cells in the shape of the letter "U" whose arms are adjacent to the posterior part of the anterior commissure. In the mole the $\mathrm{Na}$ is formed by the same morphologically cells as the caudate nucleus and putamen.

Globus pallidus $(G p)$. In $S$. araneus the globus pallidus (Gp-Fig. 2) has a central position among the nuclei of the corpus striatum. It extends from a transverse plane lying at a distance of about $720 \mu \mathrm{m}$ posteriorly to the anterior pole of the $S t$ to a transverse plane passing at a distance of about $300 \mu \mathrm{m}$ anteriorly from the posterior pole of the St. The lenght of the $G p$ is about $300 \mu \mathrm{m}$. The anterior pole of the $G p$ is formed by a small oval group of cells lying in a hollow in the medial surface of the St. In the posterior direction this cell group increases rapidly in size and its inferior border lies below the ventral surface of the St. At a distance of about $120 \mu \mathrm{m}$ from the anterior pole the $G p$ assumes at a short distance the shape of the letter " $L$ ", and increases in size in the lateral direction returning them to an oval shape. On the dorsal, lateral and partly on the ventral sides the $G p$ is adjacent to the $S t$, and the medial side meets the internal capsule. At a distance of about $350 \mu \mathrm{m}$ posteriorly to the anterior pole the globus pallidus tapers off 
and assumes the shape of a horizontally situated letter " $U$ " whose arms are adjacent to the medial surface of the St. This shape changes rapidly and the $G p$ ends as a narrow band of cells adjacent to the striatum.

The globus pallidus is formed by multipolar and fusiform cells from 15 to $25 \mu \mathrm{m}$ in diameter lying loosely between the fibres of the internal capsule. These cells contain a poorly staining nucleus with a strongly staining nucleolus and microgranular tigroid (Fig. 6, Plate IV).

In $N$. fodiens the globus pallidus has the shape and position very similar to those in $S$. araneus. Its anterior pole lies at a distance of about $1.45 \mathrm{~mm}$ posteriorly to the anterior pole of the $S t$, and its posterior pole about $400 \mu \mathrm{m}$ anteriorly to the posterior pole of the St. The length of the $G p$ is about $950 \mu \mathrm{m}$. The globus pallidus in $N$. fodiens is composed of the same cells as the $G p$ in $S$. araneus.

In the mole the globus pallidus (Gp-Fig. 4) lies between the caudate nucleus and the putamen. The anterior pole is about $2.5 \mathrm{~mm}$ posteriorly from the anterior pole of the $S t$, and the posterior pole about $450 \mu \mathrm{m}$ anteriorly from the posterior pole of the St. The length of the $G p$ is about $1.3 \mathrm{~mm}$.

The anterior pole of the $G p$ is formed by scant cells scattered between the internal capsule and the posterior part of the anterior commissure. In the posterior direction the number of cells increases and the $G p$ assumes an oval shape. About $360 \mu \mathrm{m}$ posteriorly from the anterior pole the ventral border of the $G p$ reaches below the inferior surface of the putamen. Then the $G p$ shifts dorsally and fills the hollow in the medial part of the $P t$ which limits the Gip on the dorsolateral and ventrolateral side. About $350 \mu \mathrm{m}$ from the posterior pole the globus pallidus decreases gradually in size assuming the shape of the narrow vertical cell band which disappears slowly. In T. europaea the Gp is compared of the same cells as in $S$. araneus and $N$. fodiens.

\section{DISCUSSION}

In the studied species of Insectivora the corpus striatum shows a distinct differentiation into two types: the primitive type with regressive features, represented by $S$. araneus and $N$. fodiens, and the progressive type present in T. europaea. These differences are particularly evident in the development of the striatum.

In both representatives of Soricidae, similary as in the rat (Graybiel \& Ragsdale 1979) and the mouse (Iwahori \& Mizuno 1981) the absence of striatum division into putamen and nucleus caudatus is due to poor development of the internal capsule whose main component are the fibres of the corticospinal tract. This may suggest that the cerebral cortex of these animals has a more primitive structure than that in 
T. europaea in which, similarly as in Tadarida mexicana (Humphrey 1936), the striatum is divided into two centres. However, in the caudate nucleus in T. europaea the head, corpus and tail cannot be discerned, while this division is evident in the higher Placentalia (Tamandua tetradactyla, Smith, 1930; rabbit, Younng, 1936; horse, Barone \& Reut, 1955; goat, sheep and cow, Szteyn, 1966; and man, Hewitt, 1958). The putamen in T. europaea is shaped as in the bat Tadarida mexicana (Humphrey, 1936) and much less developed than in Tamandua tetradactyla (Smith, 1930), rabbit (Young, 1936), horse (Barone \& Reut, 1955) and domestic ruminants (Szteyn, 1966).

The arrangement of cells in the striatum in Insectivora is not significantly different from that of other mammals such as Tadarida mexicana (Humphrey, 1936), rabbit (Young, 1936), domestic ruminants (Szteyn, 1966), cat and primates (Graybiel \& Ragsdale, 1978).

The nucleus accumbens is regarded by certain authors as a part of the caudate nucleus lying in the region of the septum pellucidum. This definition lacks precision. In $S$. araneus and $N$. fodiens two parts of the nucleus accumbens can be discerned: the main part lying below the striatum, and the part occupying a small segment called the septal part of the nucleus accumbens. In the mole, besides the main part of the $\mathrm{Na}$ which lies below the ventral border of the putamen, two cell aggregates are found. Thus evident differences are present in the development of the $N a$ of various species of Insectivora. In the dog (Miodonski, 1962) the $\mathrm{Na}$ is composed by two cell groups: the septal nucleus accumbens and the caudate nucleus accumbens. Szteyn (1966) discerned in domestic ruminants also two groups of cells which he called: the septal and the caudate part of the nucleus accumbens. However, in contrast to the dog, in the ruminants both these cells groups are present together only at a short distance. The cell pattern of the nucleus accumbens in Insectivora is not significantly different from that of other mammals.

The position and shape of the globus pallidus in the studied species of Insectivora are similar. The nucleus is a homogenous band of cells situated on the medial part of the striatum. A similar structure and location of the globus pallidus are observed in other mammals studieid as yet, with the exception of Primates. It man Riley (quoted by Szteyn, 1966) isolated two parts: lateral and medial. Graybiel and Ragsdale (1979) divided it in Primates into an external and an internal part. These authors believed that the internal part of the human globus pallidus is secondarily divided into a lateral and a medial part. They regardeid also that the globus pallidus in Carnivora and Rodentia was also divided into two cell groups, but this division was not so evident as in Primates. 
The cell pattern in the globus pallidus of Insectivora shows no significant species specific differences and differences from other mammals. Only few exceptions are known. For example, Iwahori and Mizuno (1981) observed that in mice the $G p$ was composed of large and medium-sized fusiform cells. The large cells were present in the central part of the globus pallidus, and the medium-sized ones were lying peripherally. Difiglia, Pasik and Pasik (1982) observed in the Gp of Macaca mulatta large fusiform cells up to $50 \mu \mathrm{m}$ in size, and small ones, about $12 \mu \mathrm{m}$ in size which they regarded as interneurons.

\section{REFERENCES}

1. Barone R. \& Reut L., 1955: La morphologie du corp strie chez les equides. Compt. Aend. Assoc. Anatomistes, 1-225, Paris.

2. Difiglia M., Pasik P. \& Pasik T., 1982: A Golgi and ultrastructural study of the monkey globus pallidus. J. comp. Neurol., 212: 53-75.

3. Graybiel A. M. \& Ragsdale C. W., 1979: Fiber connections of the basal ganglia. Prog. Brain Res., 51: 239-283.

4. Hewitt W., 1958: The development of the human caudatus and amygdaloid nuclei. J. anat., 92: 377-398.

5. Humphrey T., 1936: The telencephalon of the bat. J. comp. Neurol., 65: 603$-711$.

6. Iwahori N. \& Mizuno N., 1981: A Golgi study on the globus pallidus of the mouse. J. comp. Neurol., 197: 29-43.

7. Miodoński A., 1962: The nucleus accumbens in the brain of the dog. Acta biol. cracov., 5: 109-121.

8. Smith O., 1930: The corpus striatum, amygdala and stria terminalis of Tamandus tetrodactyla. J. comp. Neurol., 51: 65-121.

9. Szteyn St., 1966: Die Struktur und Topographie der Basalkerne der Hemisphären des Endhirns der Hauswiederkäuer. Anat. Anz., 118: 58-66.

10. Young M., 1936: The nuclear pattern and fiber connections of the non corticals centres of the telencephalon of the rabbit. J. comp. Neurol., 65: 295-380.

Received, December 20, 1985. Accepted, October 23, 1986.

Stanisław SZTEYN, Barbara GAWRONSKA i Edward SZATKOWSKI

TOPOGRAFIA I BUDOWA CORPUS STRIATUM OWADOZERNYCH

\section{Streszczente}

Zbadano kresomózgowia trzech gatunków owadożernych: Sorex araneus, Neomys fodiens i Talpa europaea. Material do badań utrwalono w parafinie i krojono na skrawki poprzeczne grubości $15 \mu \mathrm{m}$. Skrawki barwiono metodami Nissla i Klüvera - Barrery. Corpus striatum owadożernych dzieli się na striatum, nucleus ac- 
cumbens i globus pallidus. Striatum S. araneus i $N$. fodiens (St-Ryc. 1, 2, 5, 6, 7, 8) jest jednolitym pasmem komórek. Jedynie w środkowym odcinku pęczki włókien capsula interna rozdzielają częściowo centralną okolicę $S t$ na część boczną i przyśrodkową. U kreta striatum (Nc, Pt-Ryc. 3, 4, 9) jest podzielone na nucleus caudatus i putamen. Tylko w przednim i tylnym odcinku oba jądra są ze sobą zespolone. Nucleus accumbens i globus pallidus u owadożernych nie wykazują istotnych różnic gatunkowych. W porównaniu ze ssakami wyższymi u owadożernych stosunkowo słabo wykształcona jest część przyśrodkowa nucleus accumbens (nucleus accumbens pars septalis).

\section{EXPLANATION OF PLATES III-IV}

\section{Plate III}

Fig. 1. Cross section of the telencephalon of $S$. araneus at the level of the middle part of the nucleus accumbens.

Fig. 2. Cross section of the telencephalon of $S$. araneus at the level of the middle part of the globus pallidus.

Fig. 3. Cross section of the telencephalon of $T$. europaea at the level of the anterior part of the nucleus accumbens.

Fig. 4. Cross section of the telencephalon of $T$. europaea at the anterior pole of the globus pallidus.

\section{Plate IV}

Fig. 5. Cells of the striatum in S. araneus.

Fig. 6. Cells of the globus pallidus in $S$. araneus.

Fig. 7. Cells of the striatum in $N$. fodiens.

Fig. 8. Cells of the nucleus accumbens in $N$. fodiens.

Fig. ๕. Cells of the caudate nucleus in T. europaea. 

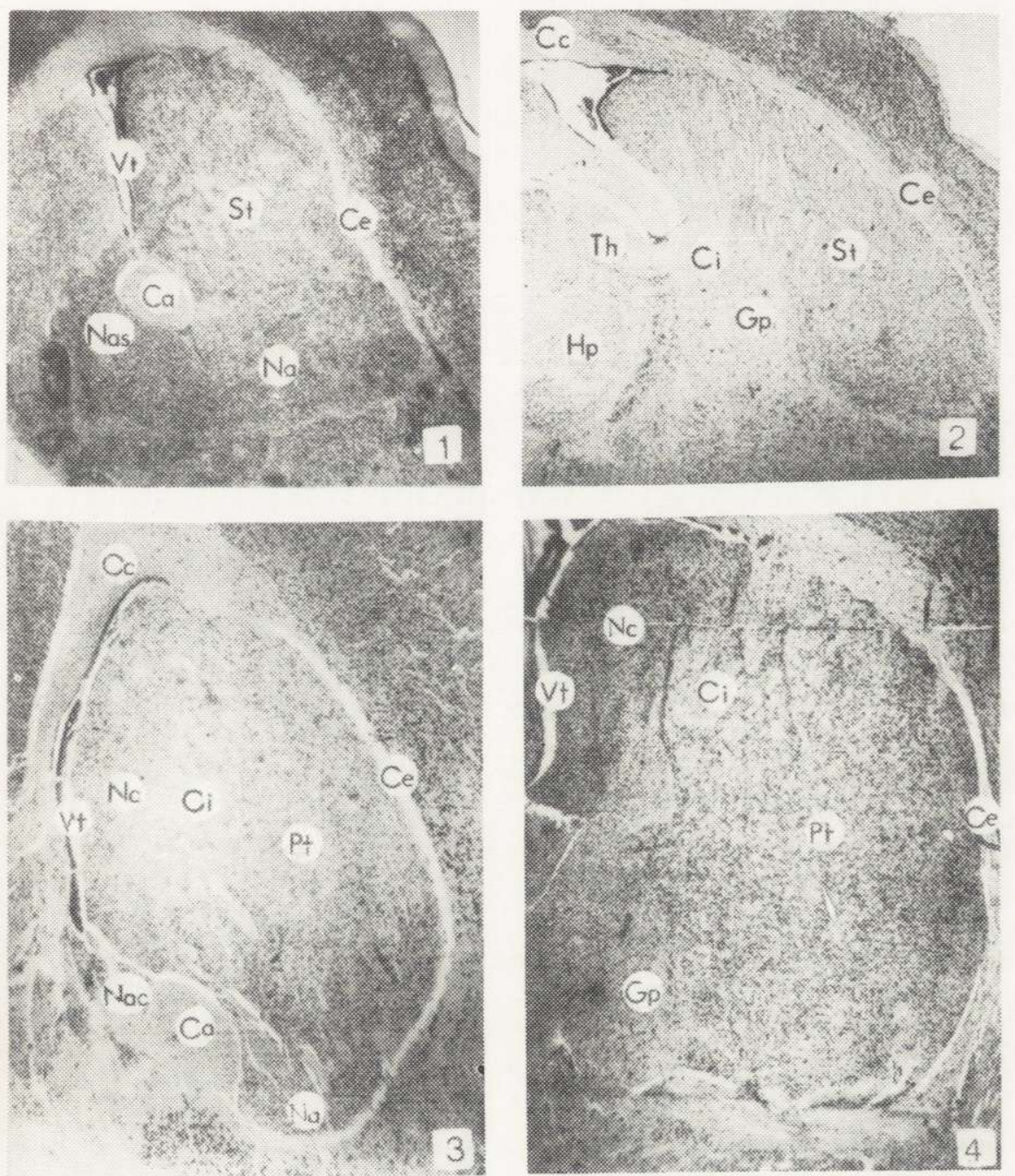

S. Szteyn et al

auctores phot. 


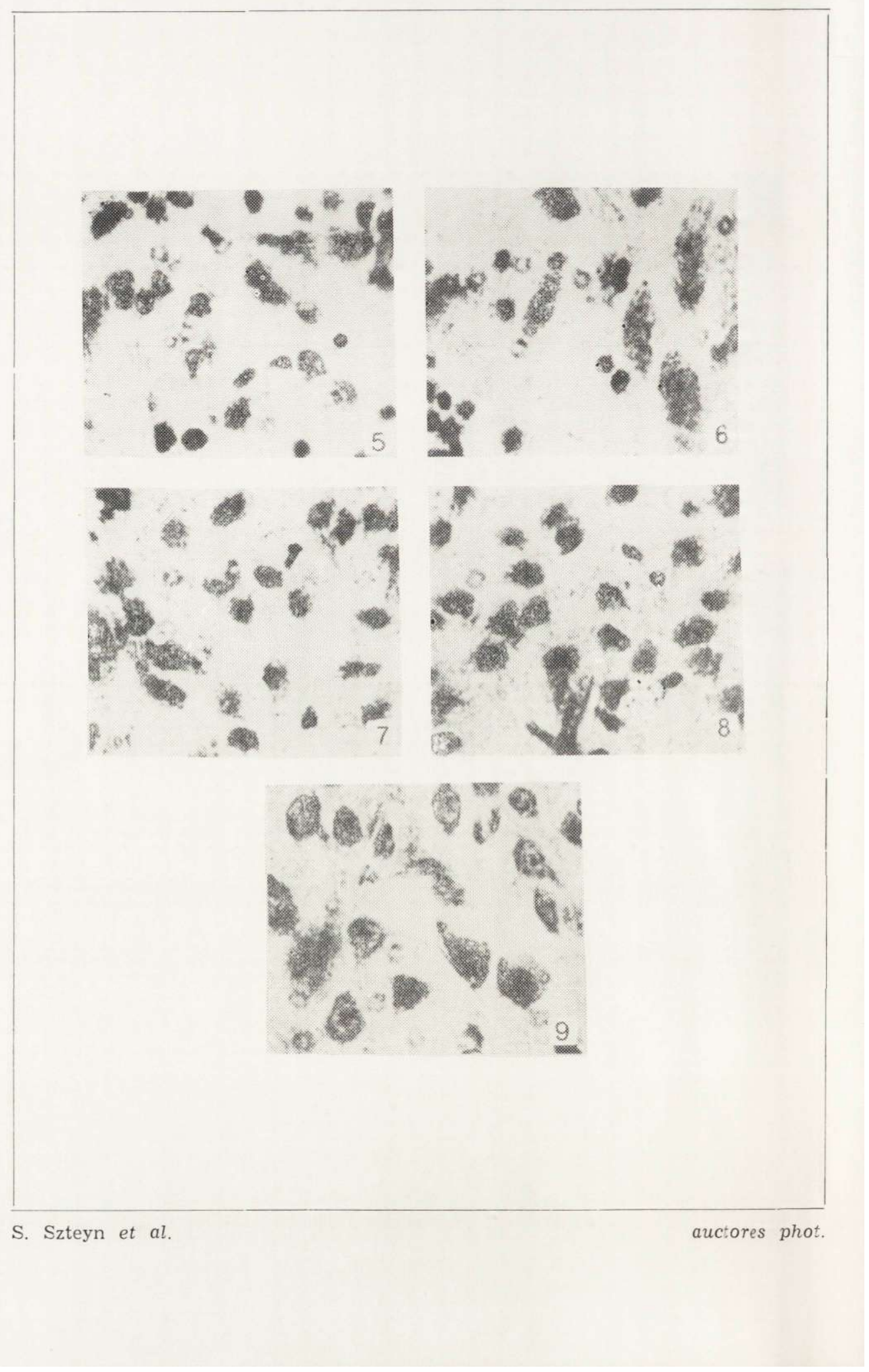

